The laws of impermanence: displacement, sovereignty, subjectivity

Raeymaekers, Timothy

Posted at the Zurich Open Repository and Archive, University of Zurich

ZORA URL: https://doi.org/10.5167/uzh-169748

Book Section

Published Version

Originally published at:

Raeymaekers, Timothy (2019). The laws of impermanence: displacement, sovereignty, subjectivity. In: Mitchell, Katharyne; Jones, Reece; Fluri, Jennifer L. Handbook on Critical Geographies of Migration. Cheltenham, UK: Edward Elgar Publishing, 58-68. 


\section{The laws of impermanence: displacement, sovereignty, subjectivity Timothy Raeymaekers}

\section{MIGRANT SUBJECTIVITY I}

To talk about borders and migration today may sound a bit like the chicken-and-the-egg debate. On the one hand, the challenge of migration has arguably forced governments to become more mobile, including in the very techniques that track, channel, filter and differentiate people's mobility across the globe. Alison Mountz's term "archipelago of sovereign control" (2011b) captures quite well how governments are continuously externalizing the cost and responsibility of asylum to third - not seldomly unaccountable - bodies. She explains how sovereign bodies (which include but are not limited to state government authorities) often exploit distance, precariousness and ambiguous political status as ways to deflect migration and responsibility over refugee rights. Typically, this process involves certain tactics of spatial distancing, exclusion and segregation, exemplified for instance in practices of offshore detention, the establishment of legal no-man's lands and security valves, and increasingly privatized surveillance (see also Jones 2016).

On the other hand, though, and often anticipating this very move, existing infrastructures (i.e., what Lindquist et al. 2012 call the "black box") of migration (the "institutions, networks and people that move migrants from one point to another") are also undergoing fundamental changes. To connect the different dots, some authors have started to contemplate the emergence of a "middle space" of migration (McKeown 2012): an ambiguous intersecting space occupied by mediators of various kinds. This space not only allows for a multitude of passages to pass through contemporary boundaries (in other words, it contests the notion of single, unidirectional flows), but it also opens our minds to the involvement of organizations that are located within, outside as well as on the brink of state government (in other words, it shifts our lens from state to global governmentalities). Slightly moving away from the classic, social network focus on embeddedness and nested scales (see, e.g., Portes and Sensenbrenner 1993; Portes 1995; Swyngedouw 1997), the emerging vocabularies of mobile "channels", "infrastructures", "punctuations", and "circulations" (e.g., Smart and Smart, 2008; Tsing 2009; Elyachar 2010; Lindquist 2017), have become the initial nodal points of such a "multi-scalar" method that is capable of identifying "strategic sites" where critical engagement can be grounded (Mezzadra and Neilson 2013; Xiang 2013, p. 282).

While today's paradigm of mobile borders is certainly a very useful one, two further signposts have to be erected here. First, the idea of the mobility of borders and their relation to regimes of classification, sorting and hierarchization is certainly not a new one. In fact, the entire endeavour of postcolonial studies has been to unveil how the colonial project was also a cultural process that sought legitimation through discourses of difference and superiority. Typically, these strategies of differentiation were actively 
implemented through essentialist boundaries of difference (for an overview see Nash 2004). So rather than asserting uniqueness, a more useful way to analyse current transformations is to ask how current strategies, of punctuation, channelling and filtering take on distinct forms and modalities in the current conjuncture. ${ }^{1}$ Second, mobile borders also produce important territorial effects (Van Houtum and Van Naerssen 2002; Painter 2010). When it comes to today's technologies of migrant asylum, for instance, they typically continue to crystallize into quite heterogeneous places such as (ex-colonial) prisons, (contemporary) reception and asylum centres, "informal" settlements, "jungles", "shantytowns and ghettos" (Deleuze 1992, p. 7) that are in various ways interconnected both with each other and with the wider systems of government that project and sustain them.

One important question that remains somewhat undervalued in the current debate is how migrant subjectivities are actively translated through the embodied experience of contemporary border politics. This is nonetheless an important question. It is important because, as Agier and Lecadet (2014) write, the daily experience of migration, which involves both the materiality and socialization that unfolds in the heterogeneous places of border governance, can gives us a more concrete idea not so much of the "camp form" as a presumably unifying structure of migrant containment (for a critical overview see Minca 2015) but rather about its ambivalence. Such embodied narrative of migration can tell us something about the way exile and displacement become integrated into possible futures, of urbanization, of citizenship, and of territorial interconnectedness; in other words, of the ways citizens and non-citizens are being separated socially, culturally, politically. To quote Agier once more (2016, p. 7), borders represent a time-space that somehow ritualizes our relationship with the Other, either through negation or negotiation, but always through cultural mediations. This seems to me a crucial insight for geographers, sociologists and anthropologists interested in the concrete experience of alterity and what it does to people's everyday lives. Based on the recognition that human mobility is in itself a highly differentiated and differentiating activity, it becomes our task, then, to assess how the boundaries of migration are actively promoted through strategies of differentiation, hierarchization and stratification, and how these become conducive in the making of migra(n)t(ing) political subjects. We need not romanticize or demonize "migrants" and "nomads" as political categories. But we need to provide situated and provisional accounts of their movement in space (Cresswell 1997).

The literature on political subjectivity offers one lens to situate migrant experiences in such a relational field of power (Das et al. 2000; Biehl et al. 2007; Das 2008). ${ }^{2}$ In this chapter, I will focus on two of its contributions. On the one hand, I will focus on the acts of translation through which this differentiation is actively performed, practised and embodied (see also Isin 2008; Andrjasevic 2009).

Second, I will concentrate more prominently the historical legacies of subordination, racism and colonial imperialism through which migrant differentiation continues to be informed and enacted today. In order to argue these two points, the rest of this chapter will develop as follows: after a short introduction into the concept of mobile bordering

1 I thank Camilla Hawthorne for this extremely useful insight.

2 I base part of these insights on previous ethnographic reflections in Greenhouse et al. (2002), Vigh (2008, 2009) and Arnaut et al. (2008). 
processes, I ask myself what kind of migrant subjectivity such processes potentially produce. Through the example of my fieldwork in the domain of the Italian asylum system, I develop a few thoughts about the relationships between migration, sovereignty and violence. In the final section, the conceptual framework of political subjectivity and of diffuse governance will help me to deconstruct the spatial processes through which social abandonment is performed, embodied and enacted in the domain of contemporary border management. The focus of the chapter involves practices of refugee asylum in Italy. Within the context of the current migration "crisis" across the Mediterranean, I present this research as a way to understand how relationality and translation play an increasingly prominent role in the subjectivation of migrant would-be (or non-)citizens in the current paradigm of diffuse territorial borders.

\section{TERRITORIALITY I}

From the perspective of migration, the tendency nowadays is to talk about territorial borders in topological rather than topographic terms (Raeymaekers 2014). Amilhat-Szary and Giraut $(2015$, p. 6) write we are witnessing a kind of epistemological breakdown currently, from the definition of the border as a palimpsest that fixes the memory of past movements, to an analysis of mobile bordering processes. Borders are complex assemblages that are not situated at the presumed margins, but in the heart of the contemporary political sphere, Balibar (2002) writes. And from there, they are capable of recalibrating the technologies of government in substantial new ways.

For our current purpose, this means, essentially, two things. For one, it is important that we continue to deconstruct the tautological relationship between territories, nations and states with regard to contemporary bordering processes. The border as a neat "line in the sand" (Williams 2006) is not only dead, but it may never have existed (AmilhatSzary and Giraut 2015, p. 9). Borders have become more fluid, more networked, more web-like. And their function has more prominently become that of a sorting device, a mobile "dispositif" (Deleuze and Guattari 1993) that serves to channel, categorize and distinguish "legitimate" from "illegitimate", "legal" from "illegal" flows. Rather than fixating movement in place, therefore, the function of territorial borders is to make authority valid in space, to regulate flows at a distance (Rose 1999; Allen 2003; Walters 2006).

Second, the complex interplay between the functions and forms of territorial borders in today's international system also highlights a renewed temporality of the border. Through the emerging technoscapes of mobile databases and technologies, borders also assume an important temporal dimension. While there exists indeed a dynamic relationship between cross-border movements, on the one hand, and the agents, devices and technologies that attempt to channel these movements, on the other, the aim of the latter is to accelerate certain flows while slowing down others. Consequently, and much in line with the observation that the territorialization of state power constitutes an effect of boundary-making practices rather than its cause (Mitchell 1991; Elden 2009; Novak 2011), the current, web-like epistemology of territorial bordering processes forces us to consider the assemblages of power that actively channel and direct flows across multiple spaces (Klatt and Anderson 2012). 


\section{TERRITORIALITY II}

If we accept, then, that borders are dynamic processes that may be associated with technologies working both through and beyond territorial states, the question becomes how sovereign power substantiates and materializes itself with regard to migrating subjects that are moving within as well as across such bordered spaces.

For the last five years, I have tried to understand this tension within the context of the so-called Mediterranean "migration crisis" - which was, arguably also, a crisis of the European border regime (Bojadžijev and Mezzadra 2015). In the aftermath of the 2010-11 Arab Revolutions - which later exploded into full-scale war in Libya and Syria - migrants from North and West Africa have been travelling in great numbers across the Mediterranean, frequently with deadly consequences. Rather than treating the Mediterranean as a conceptual "dead zone" (Saucier and Woods 2014, p. 57) marred by spectacularized demise and borderization (De Genova 2013; Cuttitta 2014), I became more interested in the ways contemporary bordering techniques remain informed by histories of racial formation and colonial memorization. Following the lead of radical feminists like bell hooks, Adrian Piper and Kimberle Crenshaw who have described marginality as a site of both separation and resistance (hooks 1990), I started to imagine contemporary border regimes as part of longer histories of displacement, segregation and persecution. ${ }^{3}$ The purpose of this research has been to also unravel the acts of translation through which migrants are both encapsulated and excluded from contemporary "acts of citizenship" (Isin 2008) -particularly with regard to the actualization of refugee rights. As Cristiana Giordano (2008, p. 592, emphasis added) writes, "the possibility of being a migrant subject [needs to be situated] at the threshold of institutional languages and their inability to provide a narrative that can account for the migrant's experience, while at the same time providing the possibility of becoming visible and recognizable as a subject" (see also Blommaert 2009; Pinelli 2013). It is this threshold, or "middle space" (McKeown 2012), that stands at the centre of my current research purpose.

Within this domain, an interesting discussion has been going on about the wider implications of the politics of historical memory, on what Judith Butler (2003, p. 52) has called the "diffuse" governmentality of undesired subjects. Reflecting on the tragedy that unfolded in the night of 2-3 October 2013, and where 386 Eritrean, Somali and Ghanaian migrants drowned in front of the Sicilian island of Lampedusa, some authors have been prone to invoking a kind of Sophoclean drama. On the one hand, the very act of mourning these deaths potentially raised the need to imagine a community "of a more complex order" (Butler 2003, p. 22) underpinned by the recognition of universal precarity and ethical responsibility (see also Gilroy 2015). On the other hand, European governments have continued to insist on the message that "Europe has to choose to be or not to be ..." (as Italy's Minister Alfano termed it on 3 October 2013) - a message that has generally resulted in more securitization, surveillance and closed border policies. More often than not though, the implementation of these bordering strategies have been diverted and diluted to organizations that have little accountability to sovereign territorial states. Just as Butler warns us, this tension risks resulting in a kind of "diffuse"

3 For Italy, see for instance Carter (2010), Merrill (2014), Hawthorne (2017). 
governmentality, whereby the right to sovereign violence is being redistributed among a range of "rogue" administrators and actors that take over the prerogatives of rule in a context of state absence. So, rather than assuming the camp form as a unifying, segregating structure, we ought to ask ourselves what this tension between migrant precarity and sovereign displacement has produced within this new constellation of the Mediterranean migration "crisis".

As the dead bodies of travelling migrants continued to wash ashore on the Sicilian coast, the Lampedusa crisis quickly intensified this Sophoclean dynamic. On the one hand, it brought about a movement of solidarity between European and African citizens across the continent that was in many ways inspired by the slogan that "we are all on the same boat". Some people joined hands with the aim of replacing national categories with new forms of transnational collaboration and belonging. Throughout 2013-14, different "migrant" occupations emerged, which waved the banner of Lampedusa as a sign of connectivity and resistance across the continent. When I started to visit some of these locations more closely in the city of Bologna, on the other hand, it became quickly clear how they also blended into existing spatial arrangements. This was particularly the case for a specific category of so-called return migrants: those refugees who, after making unsuccessful asylum claims in a second European state, were being actively sent back to Italy within the context of the Dublin Regulations (in Italian: dublinati; Bertin et al. 2013). For them, the participation in such squatting operations often became a matter of utter necessity, as they were both spatially and legally placed "out of sight" (MSF 2016). In 2016, Doctors without Borders (or Médecins Sans Frontières, MSF) used this metaphor to denounce the more or less 10,000 refugees and asylum seekers who were living in such "informal" settlements. ${ }^{4}$ Unable to legally leave the country, and often without access to an official residence, many of these dublinati remained literally stuck in these places without a proper right to the city. Consequently, their faith became illustrative of a new kind of private-public assemblage (Raeymaekers 2019 forthcoming) that is fundamentally reconfiguring migrant rights in this context.

\section{SUBJECTIVITY II}

The example of Bologna's dublinati illustrates well how migrant asylum can quickly transform itself into a permanent threshold, or a grey zone of excluded existence that reiterates rather than challenges the premises of the territorial nation-state. Caught by the isomorphism between national belonging, territorial integrity and sovereign autonomy, return refugees are actually being denied their basic human rights in the current context of diffuse border and migration governance. In Bologna, the situation unfolded like this: while various autonomous groups continued to actively propagate a political resistance to Europe's border regime over the course of 2011-15, a swathe of non-governmental

4 Quite significantly, these "informal settlements" did not include what MSF depicted as the more or less permanent labour camps in Italy's industrial agriculture areas, such as Piedmont and Puglia, where thousands of migrants flock together each year to harvest grapes, oranges and tomatoes. Part of my endeavour, and that of other scholars (see, e.g., Andrijasevic and Sacchetto 2015; Dines and Rigo 2015) has been to analyse how they are related. 
organizations gradually sought to fill the gap by providing aid in the form of legal advice and medical assistance to displaced people that had been literally abandoned by the system. Most of these latter organizations operated under the form of certain government "concessions", in which they acquired the active temporary right to implement state regulations under condition of conscious government withdrawal (for comparison see, e.g., Kritzman-Amir 2011). To some extent, therefore, this changing temporality of refugees' evictability in Europe's asylum regime reflected a kind of corrugation (or folding back) of its deterritorialized border politics in the Southern Mediterranean. One thinks automatically of countries like Libya, Senegal and Mauritania, where European states have been collaborating for years with Frontex and national border guards to hold back trans-Mediterranean migration. Politically speaking, such concessionary asylum politics actually highlights the more pressing question of who decides over people's rights, and who implements territorial sovereignty there where state governments consciously decide to outsource or even withdraw from their prerogatives to implement refugee rights. From a postcolonial perspective, this situation raises an interesting paradox, because it shows the perennially tentative character of territorial sovereignty there where the ability to decide over people's rights is actively dispersed among often competing actors and institutions (Mbembe 2001; Hansen and Stepputat 2006). Strikingly similar to the context Judith Butler is describing (of Guantanamo prison), this legal suspension has created the conditions for a privatized form of sovereign violence to take root. Embodied by various "petty" sovereigns (rogue administrators, unaccountable bodies) who literally take over the power to render unilateral decisions, they literally rule over those "ungrievable" effaced bodies whose lives are accountable to no law and do not necessitate the intervention of a legitimate authority. This ambivalence between sovereign violence and its dislocation constitutes at once the centre of the problem of contemporary migration management across the Mediterranean, because it is through the actual displacement of control that the im/mobility of migrants' rights and freedoms are being enforced in the everyday (Mountz 2011a).

The next question in this context then becomes whether the current threshold of contemporary migration regimes represents a negation, or rather a renegotiation of migrants' political subjectivity. ${ }^{5}$ The answer is, again, not a straightforward one. For one, one cannot draw a sharp line between regulating institutions and collective actions in this context, because the violence underpinning displacement thoroughly creates, sustains and transforms the interconnections between lived values and contested meanings (Biehl et al. 2007; Das 2008). Personally, I like to imagine today's asylum system in Europe as a legal and cultural grey zone: it is a liminal space, where non-citizens are made explicitly complicit in their own impermanence (Levi 1991; Raeymaekers 2019 forthcoming). Second, and rather than limiting our view to the sites of encampment, imprisonment and exclusion that migrants continue to be subjected to in this contemporary constellation, we should also continue to highlight the underlying processes of illegalization and racialization, of social and political differentiation, of protection and surveillance, of mobility and immobility, that continue to shape and modulate migrant experiences in this context. As I hopefully made clear, this process is not merely driven by the techniques

5 Again, I want to thank Camilla Hawthorne for this very useful question. 
of filtering, hierarchization and selection embodied in contemporary bordering policies. It also involves an important cultural process, which - through acts of translation and mediation - continues to reproduce, contest and transform migrants' deterritorialized and racialized status.

At the very least, therefore, these observations highlight the necessity to further deconstruct the spatial processes through which the social abandonment of migrant subjects (and particularly of refugees) is performed, embodied and enacted. Besides governing technologies, these include the everyday tactics of navigation that connect displaced people to livelihood opportunities, the brokers and mediators that both facilitate and oppress them in their determination to sustain their lives. At the same time, this contemporary condition of the displaced also tells us something about the way sovereign power, or the ability to "kill, punish and discipline with impunity" (Hansen and Stepputat 2006, p. 295) has increasingly been downgraded, outsourced and disaggregated among unaccountable actors who are not always aware of their role in sustaining this process of enforcement. Such actors include but are not limited to local volunteers and associations, as well as brokers of various kinds who are actively involved in the domain of labour intermediation, housing and social "service delivery". Following anthropological work on the postcolony, one could argue that the "margin" of the state in Europe effectively represents this expanding grey zone of relative indistinction, between the law as abstract norm (de iure), and the practice of sovereign violence by those agents who, de facto, execute and interpret its application (Das and Poole 2004). The terminology of diffuse governance explicitly extends this right to presumably autonomous groups, non-governmental organizations and other agencies that are not exercising state power in a formal sense, but, through the gaps and fissures generated by this absence, acquire a de facto right to do so.

\section{CONCLUSION: AFTER THE SPECTACLE}

After these observations it is time to go back to our main question: if, indeed, we accept that human mobility is challenging the paradigms of government nowadays, in particular in the form of partially delocalized and deterritorialized bordering processes, then how is the subjectivity of migrating subjects affected by such bordering technologies and the other way around? In the current, critical paradigm, this relationship is frequently depicted as a spectacle. In his much quoted piece, Nicholas De Genova (2013) shows how, in the context of US deportation policies, the border sets a scene of exclusion that verifies, validates and legitimates migrants' subaltern status within the receiving society through a narrative of il/legality. At the same time, however, this scene is accompanied by a shadowy and often disacknowledged obscene, which reinforces the migrants' precarious inclusion into territorial state and market dynamics. Comparing migrants' subjectivities beyond the experience of deportable subjects clearly asks for an expansion of this "shadowy" space of inclusion. In this chapter, I have tried to explain what the diffuse governmentality of contemporary bordering processes means for migrants, and particularly for refugee rights in Europe, as well as the manner in which decisions about them become entangled with the dynamics of their cultural and political renegotiation. As Judith Butler writes, diffuse governance involves the systematic outsourcement of sovereign power in the context of a 
(total or partial) legal abstention. Though this withdrawal has been pretty much noticeable in the domain of migration and border "management" across the globe, the outcomes of this process are never straightforward: in some cases, government withdrawal may produce a "rogue" administration characterized by arbitrariness and random violence. ${ }^{6}$ In other cases, it might produce an ambiguous grey zone in which undesired subjects are made complicit in their own impermanence. In the example of Italian asylum politics I shortly touched upon in this chapter, the conscious withdrawal of formal government from the domain of migration "management" to some extent has contributed to an expanding grey zone that confirms the migrants', and particularly refugees' legal limbo. But this political constellation is also altering the political subjectivity of Europe's internal borders to some extent. Particularly the rights of so-called return migrants (or dublinati) has been paradoxical in this respect. On the one hand, their hypermobile trajectories make it extremely difficult for them to get rooted into their new environments. While intentions to leave remain thwarted, and desires to stay made liable on all sorts of uncertain premises, they experience a kind of permanent threshold, or a "double absence" that continues to mark the boundary between being and non-being politically recognized and protected (Sayad 1999). On the other hand, however, the lack of official residence of these refugees in many cases is leading to a static territorial existence that reiterates rather than challenges the premises of the nation-state boundaries their rights are meant to overcome. Like the victims of the Lampedusa shipwrecks, therefore, they remain caught in a kind of Sophoclean drama whereby the sanctuary of overarching human principles is being replaced by an actual denial of their rights.

The literature on subjectivity helps us untangle two important dimensions of that process. First, it highlights the historical legacies, of racial subordination, discrimination and (neo-)colonialist practices, through which the current differentiation of migrant rights continues to be informed and enacted in many places around the world. Insisting on the "embodied effects" of practices of government (Fanon 2002, cited in Browne 2015, p.20), we are made aware of the laws of impermanence that make forced displacement today not just an epistemological but also an ontological crisis (Mountz 2011a). It is a crisis that remains fundamental to the reproduction of precarity, which leading scholars identify as the underpinning drivers of capitalist expansion across the globe (Baumann 2000; Sassen 2006; Mezzadra 2011; De Genova 2013). But it is also a crisis of routines, of predictability, and of people's normative horizons that continue to separate "the actual from the possible" in people's everyday lives (Vigh 2008, p. 10). Whether this crisis is a temporary situation or a permanent "pervasive state" (Vigh 2008, p. 16) we get to understand only when connecting our analysis of the technologies of exclusion and separation with the embodied practices that make or do not make them be worked out in space. To quote John Berger and Jean Mohr (2010, p. 11, my quotation marks): "unfreedom can only be fully recognized if an 'objective' economic system is related to the 'subjective' experience of those trapped within it".

6 In this context, the case of the German town of Burbach springs to mind. In 2014, police investigated the alleged abuse of asylum seekers in a shelter home by the staff of a private security company. The two suspects, both men in their forties, filmed and photographed each other while placing their boots on the head of an unidentified asylum seeker. To some extent, these sorts of excesses also highlight the absolute arbitrariness that marks the pathways of candidate citizens towards their suspended insertion or expulsion. 


\section{Handbook on critical geographies of migration}

\section{REFERENCES}

Agier, Michel (2016), Borderlands: Towards an Anthropology of the Cosmopolitan Condition, Cambridge and Malden, MA: Polity Press.

Agier, Michel and C. Lecadet (2014), Un monde de camps, Paris: La Decouverte.

Allen, John (2003), Lost Geographies of Power, RGS-IGB Book Series, Oxford: Blackwell.

Amilhat-Szary, Anne-Laure and F. Giraut (2015), "Borderities: the politics of contemporary mobile borders", in Borderities and the Politics of Contemporary Mobile Borders, London: Palgrave Macmillan, pp. 1-19.

Andrijasevic, Rutvica (2009), "Sex on the move: gender, subjectivity and differential inclusion", Subjectivity, 29 (1), 389-406.

Andrijasevic, Rutvica and D. Sacchetto, D. (2015), "Against the day: migrant workers and new forms of exploitation: Europe and beyond", South Atlantic Quarterly, 114 (1), 192-4.

Arnaut, K., C. Hojbjerg, and T. Raeymaekers (eds) (2008), "Gouvernance et ethnographie en temps de crise: de l'étude des ordres émergents dans l'Afrique entre guerre et paix", Politique africaine, no. 111 (dossier).

Balibar, Etienne (2002), "What is a border?" in Politics and the Other Scene, London: Verso, pp. 75-86.

Baumann, Zygmunt (2000), Liquid mMdernity, Cambridge and Malden, MA: Polity.

Berger, John and Jean Mohr (2010), A Seventh Man, London: Verso.

Bertin, Francesca, E. Fontanari and L. Gennari (2013), At the Limen. The Implementation of the Return Directive in Italy, Cyprus and Spain, Ilmenau, bis500 Digitaldruck (http://www.bis500druck.de), December.

Biehl, Joao, B. Good and A. Kleinmann (2007), Subjectivity: Ethnographic Investigations, Berkeley, Los Angeles, $\mathrm{CA}$ and London: University of California Press.

Blommaert, Jan (2009), "Language, asylum, and the national order", Current Anthropology, 50 (4), 415-41.

Bojadžijev, Manuela and S. Mezzadra (2015), "Refugee crisis or crisis of European migration policies?" FocaalBlog, 12 November.

Browne, Silvia (2015), Dark Matters: On the Surveillance of Blackness, Durham, NC: Duke University Press.

Butler, Judith (2003), Precarious Life: The Power of Mourning and Violence, London: Verso.

Carter, Donald M. (2010), Navigating the African Diaspora: The Anthropology of Invisibility, Minneapolis, MN: University of Minnesota Press.

Cresswell, Tim (1997), "Imagining the nomad: mobility and the postmodern primitive", in Georges Benko and U. Strohmayer (eds), Space and Social Theory: Interpreting Modernity and Postmodernity, Malden, MA: Blackwell, pp. 360-79.

Cuttitta, Paolo (2014), "Borderizing the island: setting and narratives of the Lampedusa border play", $A C M E$, $13(2), 196-219$.

Das, Veena (2008), "Violence, gender, and subjectivity", Annual Review of Anthropology, 37, 283-99.

Das, Veena, A. Kleinmann, M. Ramphele and S. Reynolds (2000), Violence and Subjectivity, Berkeley, Los Angeles, CA and London: University of California Press.

Das, Veena and D. Poole (2004), Anthropology in the Margins of the State, Santa Fe, School of American Research Press.

De Genova, Nicholas (2013), "Spectacles of migrant 'illegality': the scene of exclusion, the obscene of inclusion", Ethnic and Racial Studies, 36 (7), 1180-98.

Deleuze, Gilles (1992), "Postscript on the Societies of Control", October, 59 (Winter), 3-7.

Deleuze, Gilles and F. Guattari (1993), A Thousand Plateaus: Capitalism and Schizophrenia, Minneapolis, MN: University of Minnesota Press.

Dines, Nick and E. Rigo (2015), "Postcolonial citizenships and the 'refugeeization' of the workforce: migrant agricultural labor in the Italian Mezzogiorno", in Sara Ponzanesi and G. Colpani (eds), Postcolonial Transitions in Europe: Contexts, Practices and Politics, Lanham, MD: Rowman International.

Elden, Stuart (2009), Terror and Territory: The Spatial Extent of Sovereignty, Minneapolis, MN: Minnesota University Press.

Elyachar, Julia (2010), "Phatic labor, infrastructure, and the question of empowerment in Cairo", American Ethnologist, 37 (3), 452-64.

Fanon, Franz (2002), Les Damnes de la terre, Paris: Editions la decouverte et Syros.

Gilroy, Paul (2015), "Offshore humanism", Antipode RGS-IBG Lecture, Exeter.

Giordano, Cristiana (2008), "Practices of translation and the making of migrant subjectivities in contemporary Italy", American Ethnologist, 35 (4), 588-606.

Greenhouse, Carol J., E. Mertz and K.B.B. Warren (eds) (2002), Ethnography in Unstable Places: Everyday Lives in Contexts of Dramatic Political Change, Durham, NC: Duke University Press.

Hansen, Thomas B. and F. Stepputat (2006), "Sovereignty revisited", Annual Review of Anthropology, 35, 295 -315. Hawthorne, Camilla (2017), "In search of black Italia", Transition, 123, 152-74.

hooks, b. (1990), "Marginality as site of resistance", in Russell Ferguson, M. Gever, M.T. Minh-ha and C. West (eds), Out There: Marginalization and Contemporary Cultures, Cambridge, MA: MIT Press, pp. 341-3. 
Isin, Elin (ed.) (2008), Acts of Citizenship, London and New York: Zed Books.

Jones, Reece (2016), Violent Borders: Refugees and the Right to Move, London: Verso.

Klatt, Martin and D.J. Anderson (2012), The Border Multiple: The Practicing of Borders between Public Policy and Everyday Life in a Re-scaling Europe, London and New York: Routledge.

Kritzman-Amir, Talin (2011), "Privatization and delegation of state authority in asylum systems", Law \& Ethics of Human Rights, 5 (1), 193-215.

Levi, Primo (1991), I sommersi e i salvati, Torino: Einaudi.

Lindquist, J. (2017), "Brokers, channels, infrastructure: moving migrant labor in the Indonesian-Malaysian oil palm complex", Mobilities, 12 (2), 213-26.

Lindquist, J., B. Xiang, and B.S.A. Yeoh (2012), "Opening the black box of migration: brokers, the organization of transnational mobility and the changing political economy in Asia", Pacific Affairs, 85 (1), 7-19.

Mbembe, Achille (2001), On the Postcolony, Berkeley, CA: University of California Press.

McKeown, A. (2012), "How the box became black: brokers and the creation of the free migrant", Pacific Affairs, 85 (1), 21-45.

Merrill, Heather (2014), "Postcolonial borderlands: black life worlds and relational place in Turin, Italy", ACME, 13 (2), 263-94.

Mezzadra, Sandro (2011), "How many histories of labour? Towards a theory of postcolonial capitalism", Postcolonial Studies, 14 (2), 151-70.

Mezzadra, Sandro and B. Neilson (2013), Border as Method, or, the Multiplication of Labor, Durham, NC and London: Duke University Press.

Minca, Claudio (2015), "Geographies of the camp", Political Geography, 49 (November), 74-83.

Mitchell, Tim (1991), "The limits of the state. Beyond statist approaches and their critics", American Political Science Review, 85 (1), 77-96.

Mountz, Alison (2011a), "Specters at the port of entry: understanding state mobilities through an ontology of exclusion", Mobilities, 6 (3), 317-34.

Mountz, Alison (2011b), "The enforcement archipelago: detention, haunting, and asylum on islands", Political Geography, 30 (3), 118-28.

MSF (2016), Out of Sight: Asylum Seekers and Refugees in Italy, Informal Settlements and Social Marginalization, Brussels: Médecins Sans Frontières.

Nash, Carolyn (2004), "Postcolonial geographies: spatial narratives of inequality and interconnection", in Paul Cloke and P. Crang (eds), Envisioning Human Geographies, London and New York: Routledge, pp. 114-27.

Novak, Paolo (2011), "The flexible territoriality of borders", Geopolitics, 16 (4), 741-67

Painter, John (2010), "Rethinking teritory", Antipode, 42 (5), 1090-118.

Pinelli, Barbara (2013), "Silenzio dello stato, voce delle donne: abbandono e sofferenza nell'asilo politico e nella sua assenza", Antropologia, 15, 85-108.

Portes, Alajandro (ed.) (1995), The Economic Sociology of Immigration: Essays on Networks, Ethnicity, and Entrepreneurship, New York: Russell Sage Foundation.

Portes, Alajandro and J. Sensenbrenner (1993), "Embeddedness and immigration: notes on the social determinants of economic action", American Journal of Sociology, 98 (6), 1320-50.

Raeymaekers, T. (2014) What is a Border? Posted on http://www.timothyraeymaekers.net/2014/10/518/.

Raeymaekers, T. (forthcoming 2019), "Liquid thresholds: migrant territories and the Mediterranean crisis", Social and Cultural Geography.

Rose, Nicholas (1999), Powers of Freedom: Reframing Political Thought, Cambridge: Cambridge University Press.

Sassen, Saskia (2006), Territory, Authority, Rights: From Medieval to Global Assemblages, Princeton, NJ: Princeton University Press.

Saucier, Khalil and T.P. Woods (2014), "Ex aqua: the Mediterranean basin, Africans on the move and the politics of policing", Theoria, $141(61,4), 55-75$.

Sayad, Abdelmalek (1999), La double absence: des illusions de l'émigré aux souffrances de l'immigré, Paris: Editions Seuil.

Smart, Alan and J. Smart (2008), "Time-space punctuation: Hong Kong's border regime and limits on mobility", Pacific Affairs, 81 (2), 175-93.

Swyngedouw, Eric (1997), "Neither global nor local: 'glocalization' and the politics of scale", in K. Cox (ed.), Spaces of Globalization. Reasserting the Power of the Local, New York: The Guilford Press, pp. 137-66.

Tsing, Anna (2009), "Supply-chains and the human condition", Rethinking Marxism: A Journal of Economics, Culture \& Society, 21 (2), 148-76.

Van Houtum, Henk and T. Van Naerssen (2002), "Bordering, ordering and othering", Journal or Economic and Social Geography, 93 (2), 125-36.

Vigh, Henrik (2008), "Crisis and chronicity: anthropological perspectives on continuous conflict and decline", Ethnos, 73 (1), 5-24.

Vigh, Henrik (2009), "Motion squared: a second look at the concept of social navigation", Anthropological Theory, 9 (4), 419-38. 


\section{Handbook on critical geographies of migration}

Walters, William (2006), "Rethinking borders beyond the state", Comparative European Politics, 4, 141-59. Williams, John (2006), The Ethics of Territorial Borders: Drawing Lines in the Sifting Sand, Basingstoke: Palgrave Macmillan.

Xiang, Biao (2013), "Multi-scalar ethnography: an approach for critical engagement with migration and social change", Ethnography, 14 (3), 282-99. 